\title{
Pramoedya Ananta Toer's Voice for Humanity Values vs. Javanese Tradition in The Girl from the Coast'
}

\author{
Ida Puspita \\ Ahmad Dahlan University
}

\begin{abstract}
Pramoedya Ananta Toer, an Indonesian leading prose writer in 1940s to 1960 s, deeply understands that authors have great role in creating good sense in society through their works. Pramoedya often reflects the struggle for raising. human dignity in his compositions. His critical attitude in expressing the social change often makes him in conflict with the state power. Consequently, Indonesian government banned his works for a long time, but international world welcomes them positively. He loads his works with messages of humanity values appreciation that mostly are not in line with local culture values in the works. Pramoedya often sets his stories in Javanese culture, which is believed to have practiced a number of worldviews related to the degradation of humanity values. The Girl from the Coast is one of Pramoedya's works containing contradiction between these two different sides of values.

The Girl from the Coast loaded with a deeply personal source portrays a nameless Javanese teenage girl facing difficult problem in her life becoming a 'practice wife' of a Javanese aristocrat (Bendoro) and becoming a commoner. It tells the story of Pramoedya's matemal grandmother and based on stories he had heard about her, her life as he had witnessed it while still a child, and his imagination. The work contains some concepts that deteriorate the humankind values. These values encompass different position of woman and man, nobility and commoner, and violence in maintaining the nobility's worldview. By using content analysis, this paper attempts to reveal Pramoedya's.effort in voicing his concept on humanity values, which are contradictive with the Javanese tradition in the earlier time.
\end{abstract}

Keywords: humanity values, Javanese tradition, commoner, ṇobility

\footnotetext{
${ }^{1}$ Presented in The 6th Malaysia International Conference on Languages, Literatures, and Cultures, 28-30 April 2009 held by Department of English, Faculty of Modem Languages and Communication Universiti Purra Malaysia Sendang MALAYSIA
} 


\section{A. Opening Remarks}

As the first of a proposed trilogy, the book tells the story of Pramoedya's maternal grandmother and is based on stories.he had heard about her, her life as he had witnessed it while still a child, and his imagination. It is, thus, not completely fact, nor is it completely fiction. Joy Press in his article titled Bound to Java's Huts explained that the second and third books have been lost. The second dealt with Pramoedya's father generation and their problems of co-operation (and noncooperation) with the Dutch. The third dealt with the Indonesian military and the struggle for independence, the issue confronted by his own generation (http://www.villagevoice.com/books/0234,press.37590,10.html). The nameless title character of this novel comes from a remote fishing village on the north coast of Java that is itself never named in the turn of the $19^{\text {th }}$ century. Indeed, her father, mother, husband and beloved servant are never named either.

Pramoedya opened the story with a nobleman from nearby city, a Bendoro, who caught the beauty of the main character, the Girl. Her parents decided to accept the Bendoro's marriage proposal and the unusual process of a wedding for at least three reasons. First, they wanted their daughter to be free from poverty. Second, as impoverished people, they had no power to refuse the proposal given by the privileged people. Lastly, it was a pride to have son in law from nobility. As for the Girl, after the marriage, she met a different life literally and figuratively in the city comparing to the one in the village. Pramoedya brilliantly evoked the impression of puzzlement of the Girl when she first came across the stuff such as mattresses, electric lights, and chocolate sprinkles for cereal. Moreover, the writer masterfully depicts how the twofold chain of order of the Javanese aristocracy and Dutch colonialists construct a hypocritical world that consider women as no more than material assets. (Bloomstran, http://www.mostlyfiction.com/world/toer.htm)

There are a number of reviews towards the novel and the author. First, Andrea Kempf, a professor and librarian at Johnson County Community College writes that the graceful narrative tells a universal story, of an individual who is victimized by societal structures and could survive despite the cruelty of those in power. The Girl from the Coast is an excellent introduction to the works of a master storyteller who has never compromised his principles and who has become a symbol of the defiance of tyranny everywhere (http://www.persimmonmag.com/winter2003/bookreview3.html). In line with this, I.B. Manuaba (2003) 
asserts that Pramoedya's brave criticism. in voicing and expressing the development of the era makes his works banned by the Indonesian New Order government for a long time. Moreover, many of those works load messages about the struggle of human beings to rise up their dignity as the foundation to build a country. Yet, these credible masterpieces gained positive welcome from the international world (p. 276-277).

Through his characters, especially the Girl, Pramoedya depicts the collision between humanism and the Java's tradition in the early 20th-century in the Dutch East Indies. The writer shares his criticisms through the voice of the characters in the novel, particularly, those who act as the commoners. The main character, the Girl, who meets these two different ways of life, questions many unreasonable concepts happened in the world of Javanese nobility based on her perspective and background from the fishing village as she becomes the ideological vehicle for Pramoedya in voicing his principle. In the novel, the Girl who is believed to represent Pramoedya's grandmother brings the ideas of oppression towards the inferior class carried out by the Javanese superior class. The phenomenon was not only fictional but he also witnessed it when his grandmother could only address her own daughter and son in law with ndoro, a title for privileged people (Toer, 1997, p.19-20).

Pramoedya has received a number of tributes, and was regularly discussed as Indonesia and Southeast Asia's best candidate for a Nobel Prize in Literature. Born on February 6, 1925, in the town of Blora in the heartland of Java, then a part of the Dutch East Indies, he was the firstborn-son in his family; his father was a teacher, who was also active in Boedi Oetomo, and his mother was a rice trader. His name was actually Pramoedya Ananta Mastoer; however, he felt that the family name Mastoer (his father's name) seemed too aristocratic. The Javanese prefix Mas refers to a man of the lowest rank in a noble family. Consequently, he omitted Mas and kept Toer as his family name (as cited in Puspita, 2009, p. 103).

Since this work is a serious fiction loading his grandmother's experiences, the readers can listen to the creator through his creation related to his personal life. Related to this, Jason and Lefcovitz (as cited in Herujiyanto, 2007, p. 13-14) say that prose fiction contains the history of one or more characters, or something that acts like a character. The very character(s) can also be representative(s) of the writer him/herself; that the work is made of the author's special flight of 
imagination, of cultural aspects and pedagogy, which is grounded in her or his accumulated experiences thus, the work has a significant relation to the world of actuality. According to Fauzie (2003; p. 206), Pramoedya is an author who has capability to take historical reality in writing a literary work with the intention to create a historical realism.within a fiction. In addition, he has a unique quality in creating vividly characters in either his own history or the society's history in certain historical period through his work. Therefore, the old - fashioned biographical approach can still be a useful tool to look into the work and to get a better understanding. The novel has been widely translated into many western languages; thus, the international readers can learn about Indonesia from this source. It is particularly remarkable to expose the culture that exists in Indonesia represented in the novel through the notions of Javanese tradition conducted by the nobility (priyayi) and the Javanese villagers in the North Coast of Java island.

Manuaba asserts that many of Pramoedya's works load messages towards humanity and degradation of these values. The very outstanding characteristic makes him becomes such a phenomenal writer (2003, p. 276). Even though Pramoedya has a huge numbers of criticisms on humanity degradation in his works, in this paper, the writer will only focus on the humanity values voiced by Pramoedya, which are in contrast with the existing Javanese tradition practiced in The Girlfrom the Coast's setting of time.

\section{B. Pramoedya's Concept about Javanese Culture}

In his works including this novel, Pramoedya often sets his novel in Java as his brand image. Besides being his place of birth, Java also acts as the cultural setting of his life. He is indeed proud of the Javanese culture that contributes much to his way in seeing the world. Pramoedya grows in a family of Javanese aristocracy, for his father, Mastoer, is from Klaten, a suburb area, and his mother, Saidah, came from Rembang, a coastal area. His father was liberal and Javanese minded. He did not practice Islamic teaching and disliked the practice of feudalism. However, almost without realizing it, he had no objection toward the Javanese-feudal culture (Toer, 1997, p. 3).

Mastoer had a close relation with the Javanese culture since he came from a suburb Javanese area. On the contrary, Saidah who was from a Javanese coastal 
area had a strong Islamic ideology. She practiced Islamic praying as she had lived. in a religious surrounding among the nobility; however, she did not obligate her children to do the same thing. She obtained religious teaching and a private teacher in the house and western education in the school. Consequently, Pramoedya's mother has insufficient knowledge about Javanese culture until Pramoedya has -grown up (Toer, 1997, p. 4). Her memoirs were described-through the life and education of Bendoro's children in the novel. In fact, one of the Bendoro's children is Pramoedya's mother because the main character in this novel (the Girl) represents his grandmother who became the Bendoro's practice wife.

\section{a. Wayang (Puppetry)}

Pramoedya knew Javanese culture from his father who often took him to watch wayang (puppetry) after teaching him in the aftemoon. His father loved to create Javanese expression and song and taught them to his students in the school. Sometimes, if Pramoedya had a.conflict with his father, he left the house and watched wayang performance for the whole night. Nevertheless, this hobby will change considerably when he grows up later.

In Nyanyi Sunyi Seorang Bisu (1995), Pramoedya told his experience when he watched wayang kulit (puppetry made of leather) performance in Pulau Buru prison. Wayang is the reflection of the world controlled by the dominant class since the stories of wayang are mostly about gods, brahmana (priests), and ksatria (knights). Meanwhile, the lower class people characters have little part in the story, and their job is only to entertain or to please the dominant class. In the last part of his writing, he wrote his decision to stop watching wayang, staying all night, and sneaking away from the study and family obligation since 1939. In his opinion, Pandawa represented the corrupted behavior in which it was contradictive with the belief of the common Javanese people. These people have different thought from Pramoedya about Pandawa. For them, Pandawa, in their discarding, represented the Javanese people themselves who at that time became discarded by the Dutch from their own land. The ideological agents who represented the upper class people interest spread this idea; thus, the common Javanese people had the same perspective about the story of wayang. As a result, when eventually Pandawa defeated Kurawa, Pramoedya and these people have different attitude in which it was clear for Pramoedya that this conquest symbolizes the continuity of 
oppression done by the Javanese upper class people who will somehow . sustained the wayang to spread their values over the commoners (p. 38-40).

Pramoedya's dislike towards wayang was pictured in the novel through the characters of the old man and the villagers in the fishing village. The old man was furious to the city man who tried to bring wayang to the village. He believed that the dominant class people used wayang as a-tool to maintain their position in the society.

"Your sin, brat of a city man, lies in wanting to trick us with your puppets!" ... "You'd sell us lies. The puppets are only pieces of leather. You cut them out yourself and painted them fancy colors. But you'd be telling us how great the different figures are. How powerful they are. Unlike anything else in the world.All lies...."(Toer, 1991,p. 54)

Wayang contains many stories illustrating the services done by the commoners, as a form of subordination of the privileged people towards the commoners. Therefore, the villagers as the commoners do not like wayang as the symbol to perpetuate the superior class. In Javanese cultural perspective, wayang is an art contains characters of Gods, kings, princes, and servants or clowns (the typical individuals treated like subhuman beings), and relationship among them. In wayang, gods' position is irresistible as the symbol of the dominant class position. The Javanese people in the city believe that wayang is their ancestor as it is the sea for the villagers. The dislike of the villagers towards wayang can be seen through The Girl's story to mBok her female servant.

"People in fishing villages won't even say the word 'wayang', mBok. They don't like it at all."

"They don't underštand, Mas Nganten. The puppets are our ancestors."

"Our ancestors are dead, mBok. The sea goes on forever." (Toer, 1991:

86)

\section{b. Husband-wife relationship}

In fact, the relationship between his father and mother also shapes Pramoedya's worldview toward patriarchal Javanese culture. In this case, his father was still loyal to the Javanese aristocracy custom that accommodates his relatives' children to live in his house. Their purpose is to learn how to be.an 
aristocrat. When Pramoedya reached the age of two, there were around 15 children stayed in his father's house. It was very ironic since his father's finance. is insufficient to take a great responsibility for those children. To make it more difficult, his decision to move from HIS to Instituut Boedi Oetomo made his salary was unreliable. His father who came from Blora was an influential figure in Indonesian history. Therefore, he has little time to take care of his family. He used most of his time to get involved in politics and delegate the domestic matter to his wife. Pramoedya criticizes this custom by putting his experience in the plot of the novel. Bendoro had many nephews in his mansion, and as a Bendoro Bupati, he often left his house and let the Girl (his practice wife) to do domestic job.

The closing of $\mathrm{BO}$ and the coming of Malaise era indicated his father's economic degradation. In this complicated era, Pramoedya's mother acted as the backbone of the family. She carried out any kind of job that she had never done previously since she came from an aristocrat family. She had never complained to the condition because she is a type of Javanese woman who is always obedient to her husband. She had never criticized his husband although she deeply realizes that since the economic crisis stroke her family, her husband seldom stayed in the house. He spent most of his time to daydream and gave less attention to the family. At this moment, Pramoedya expressed his protest in the following quotation:

In the life of Javanese family tradition, when a husband gets his success and even his sorrow, a wife is usually exhorted behind. In the wife's silence, they witness their husbands' success and carry all burdens. Despite their struggle and sacrifice, the Javanese feudal people keep spreading their belief that if a husband gets a heaven, his wife will also get the heaven. However, if a husband has to go to the hell, his wife will also follow him. In other words, if the men are prosperous, the women will take the benefit. Nonetheless, if the men are suffering, the women must suffer as well. (Toer, 1997, p. 8).

- Pramoedya bore this attitude through the voice of Emak in the novel, "when a woman marries, child, she becomes bad if her man is bad, and good if he is good." (Toer, 1991, p. 3). Her mother's consciousness has been shaped long time before the Girl was born also spreads the ideology to her daughter. 
"A woman has to be with her husband. I've had to follow your father about," the mother said consolingly. "Even if shelies in a shabby old hut, even if she isn't happy, a woman's one duty is to learn to make her husband happy." (Toer, 1991, p.41)

In the novel, Pramoedya further pictured that the Girl found the inequality position between husband and wife. It happened since in the very beginning of her marriage when Bendoro sent a dagger to marry her. The disharmony of husband and wife became even more noticeable after the marriage, for the Girl's concerns were only in the domestic life such as keeping the Bendoro's properties and pleasing him. As a couple, they had never discussed anything. dealing with the Bendoro's job, which it was different from what happened in her village in which husband and wife often shared thought and opinion together. Pramoedya's voice appears in the conversation between Mbok and the Girl below.

"Have you ever lived in a fishing village, Mbok?"

"Husbands and wives treat each other differently there."

"I know. They eat together, sit together, drink coffee together. When the man is home from the sea, they talked about all sorts of things."

"Men have their work to do, Mas Nganten. It's nothing to do with us women. Leave him to it. We have our own affairs to attend to. The house is our territory; that's what we should be looking after." (Toer, 1991, p. 4849)

Another proof of the disparity relationship between the spouses exists in the following Bendoro's statement when the Girl wants to take his permission to visit her parents in the village.

"You belong to me. I decide what you can and cannot, will and will not do.

Be quiet now...."(Toer, 1991, p. 89)

This inequality, furthermore, appears in the Girl's life as a Bendoro's wife who always feels under pressured and dependent. She was always under her husband's command as for Bendoro, the Girl is considered only as co-worker or kanca wingking, which in Javanese value, it shows the role of a wife that is restricted in the domestic life, covering kitchen and bedroom affair. Likewise, 
she was not allowed to go out from the house, while Bendoro could go wherever and whenever he wanted to without telling his wife.

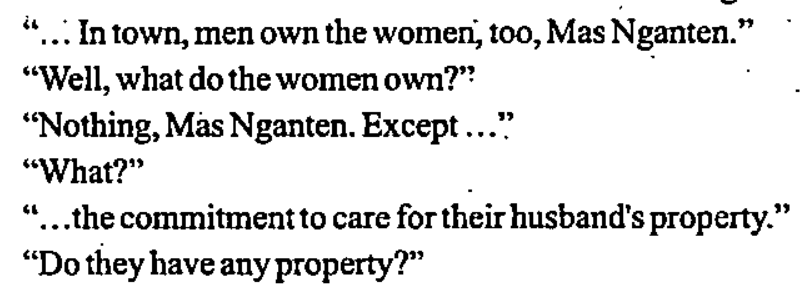

"No, Mas Nganten. They are their husband's property." (Toer, 1991, p. 55-

56)

To make the matter worse, Mbok also told the Girl about her former husband's treatment toward her.

"Did they ever hit you, Mbok?"

"Perhaps Allah created woman, Mas Nganten, so that man could beat her.

..."(Toer, 1991, p.61).

The previous quotations indicate that disharmonious relationship between spouses occurs in the city; hence, in the village, the Girl perceived the wellproportioned relationship between the spouses. In the nobility life, the wives were not allowed to interfere and criticize their husbands' businesses since their right was on the domestic life of their husbands' households. Therefore, gender inequalities exist in the story in which it is stated that men own the whole world, and even the women are considered to be their property. Meanwhile, the women have nothing except the commitment to take care of their husbands' property. They are no more worth to the men than a table, a chair, a cupboard, and a mattress. In addition, they were proper to get physical mistreatment as what Mbok experienced from hèr husband.

Pramoedya additionally revealed the humanity violence conducted by Bendoro toward the Girl, three months after she had delivered a baby. Bendoro divorced the Girl as he used to do this to many other women before the Girl. The Girl tried hard to take the baby with her, but it failed. In a patriarchal feudal system, the baby born from an impoverished mother and privileged father should follow the father. Pramoedya proclaimed his protest toward this inequitable value by picturing the courage of the Girl in defending her daughter mentally and physically although she failed to take the baby as Bendoro used a 
coercive power in intimidating her. The most important thing is the writer has expressed his resistance toward the cruelty done by the dominant class through the Girl's effort.

"You criminal!" snapped the Bendoro. "Let go of the baby! Do you want me to call the police? Or the constabulary?"' (Toer, 1991, p. 180)

It was believed that a number of the nobles practiced divorcing the concubines after delivering their babies in the former time. Kuntowijoyo declared that if one of the concubines was expecting a baby, one of them would be divorced to give place for the pregnant concubine. However, when the pregnant one had delivered the baby, she would be divorced as well $(2006, \mathrm{p}$. 34). Pramoedya attempted to resist this tradition by portraying the remarkable effort of the Girl in defending her right on the baby.

\section{c. Noble vs. Coimmoner}

In the first part of the novel, it was stated that the Girl learned the values performed by her parents and the villagers in the fishing village. Her daily activities were only mending the fishing net and pounding the shrimp to help her parents, and she went through her life happily without complaining. When someday a messenger of a noble came and brought a keris as the representative of the noble who wanted to marry her, her parents directly approved since they regarded it as a grace. Her parents had realized the social rank in practiced by the Javanese feudal society so that they were happy because the marriage could raise their daughter's position to become a member of the nobility.

"Hush; don't cry. From today onwards you'll be the wife of a rich man."

She sobbed, wept, then finally howled. In fourteen years she had never felt poor. (Toer, 1991, p. 2).

As a child, the Girl who did not understand what was happening should obey her parents although she was afraid and morose. She did not want to leave her life in the village; therefore, she did not care when her mother kept persuading her to the honor and fortune that she would get to have a noble as her husband. The Girl was a plain girl who saw everyone is equal. She had not understood the social classes in the society determined by wealth, rank and heredity. In her opinion, the factor that determines the rank of the human beings 
is when they could be beneficial to the other ones. She used this standard to value the Bendoro whom she never met previously.

Him? Who is he? The Girl from the Coast closed her eyes. She could not picture him. Was he a better man than Tumpon, her brother, who had been lost at sea when a storm attacked his boat? Was he better than Kantang, who had tried to free a net from a coral reef and never surfaced again? There was only a spreading patch of red which the sea took back again once the sharks had ripped his belly open. Would this man give his life for his family, the way Kantang had? (Toer, 1991, p. 3)

All human is created equal and indicated by his efforts to sufficient his needs and others. This principle becomes a big question of the Girl's marriage wondering on how excellent the Bendoro is to sustain his life, family and humanity. The villagers including the Girl regarded a person to be great and meritorious if he or she had courage to sacrifice for her or his family and the people in the village. The Girl was raised in the circumstance that did not differentiate human beings from their heredity, noble rank or race. Believing that human is created equal is a characteristic of humanism value voiced by the writer through the nature of the villagers.

Nevertheless, the Girl and her parents could not reject the proposal since they were impoverished villagers destined to serve the upper class people and prohibited to show any disapproval. They were submitted to the stronger power of Javanese feudal aristocrats. As what Pramoedya said in the novel, "The one whom we worship and revere has willed that we should both be dependent on members of the upper class. Without the working class, there can be no upper class." (1991, p. 64) It was believed that the power of Javanese aristocrats was destined by God and destined by nature. It was traceable in the ancierit Hindu and Islamic Indonesian kingdoms. A king was elected based on his ability and revelation. The revelation became a legitimacy tool to have a strong power; therefore, the king could dominate the land in his area and divided it to his loyal followers (Moedjanto, 2001, p. xii-xiti).

Dr. J. Kadjat Hartojo in his preface for Kuntowijoyo's book (2006) asserted that the king sees the nobility (priyayi) and commoners as the servants who must sit on the floor, meanwhile the priyayi and commoners see the king as the one who has legitimate power over the kingdom through the belief in his 
revelation. In addition, priyayi sees the commoners as the people who have no symbols of power; thus, they are inferior and uneducated (p. xxiv). Hereinafter, the legitimacy went from one generation to the next generations based on heredity lines to maintain the power of the priyayi. Therefore, the social mobility into the Javanese feudal society was very hard to take place. Antonio Gramsci stated that the feudal society pretend to create a universal worldview and involve the common people's role. They call themselves the leaders of the society, but the collective leadership appears to be the disguise the dominant class' interest as the exploitation to the lower class people continues (Suseno, 2005, p. 194).

Mary Douglas (as cited in Kuntowijoyo) said that all experiences of the people are obtained from structured system of symbols in society. Furthermore, Berger and Luckmann (as cited in. Kuntowijoyo) stated that society sees reality by indirection, which has been socially constructed. In this extent, the Javanese noblemen see the commoners as servants who have to sit on the floor, and have no symbol of power. Therefore, they are low, rude, and uneducated. Meanwhile, the commoners see the noblemen as the ones who have symbol of power. Both social classes understand their position through symbols or social construction. (2006, p. 10)

The girl stood up from her chair. The servant bowed to her. A very low bow. Why was she bowing? A few moments ago they had been equals. Why had the woman suddenly changed her behavior? The Girl from the Coast was nervous, frightened, suspicious. What is happening? Where is she taking me? Why I can't be with my parents? The Girl wanted to scream. (Toer, 1991, p. 12)

- The previous paragraph is Pramoedya's disapproval toward the tradition of bowing for the common people to the aristocrats through the scared feeling of the Girl encountering with the strange phenomena in the city. The relation and attitude of the people can change in just a few minutes if the existing society's worldview has determined their different positions as reflected in the preceding quotation between $\mathrm{mBo}$, a servant and the Girl, a commoner who became a noble after being married by a bendoro. At first, they have the same attitude as commoners, yet it changed directly after the Girl is officially acknowledged as a wife of a noble. 
The Girl learned about the social classes consisting of commoners, Javanese nobility (King and priyayi), and the Dutch from Mbok. The Girl discovered that the obligation of the commoner was to serve without any defect towards the upper class people who have the legitimate right to give order. As the Girl had become the member of the upper class people after the marriage with a Bendoro, she could give order to the common folks; however, she could not change her commoner origin. In other word, her status was only temporary before the Bendoro decided to have a real marriage with the person in the same social rank, yet the Girl had not fully realized this fact (Toer, 1991, p. 63). Although the Girl had the power to give command, she was not comfortable of doing it.

"No, Mas Nganten," the servant tirelessly reminded her. "The firstlady doesn't just talk to anyone. She gives order. Firmly. It doesn't matter what they think; they are here to do as you tell them. And so am I, Mas Nganten." (Toer, 1991, p. 51)

The Girl was reluctant to give order as she felt that every man has the same position. The author loads the message about humanity values through the Girl.

Humanism is an attitude of mind attach in prime importance to man and human values. It more properly embraced any attitude exalting man's relationship to God, his free will, his superiority over nature. Philosophically, humanism made man the measure of all things. In its return to humanism found inspiration in man's personal quest for truth and goodness. Confining systems of philosophy, religious dogmas, and abstract reasoning were shunned in favor of human. values. (Encyclopedia Britannica, 1979, p. 199)

In other words, humanism upholds value and dignity of human and puts human as the center point with the main purpose to activate humanity sense and stimulate mutual relationship among people. In this novel, the Girl wanted to keep this value although she had been a wife of aristocrat who had higher social prestige than her parents and other common villagers. In short, she still wanted to live equally as other people, such as her subordinates. The Girl was a woman born and grown in a rural community in which there is no discrimination in the terms of ethnicity, wealth, race, etc. 
Living as an aristocrat's wife whose authority to control her servants did not make the Girl to be delirious. This is-clearly shown from how loving she was toward her servant, Mbok, whom she.might order and instruct as she wished. She was not arbitrary to Mbok, and even she built friendship notion with her. They shared stories and experiences of life that strengthened love and affection between them. (Toer, 1991, p. 62)

After being the Bendoro's wife, people must address her as Mas Nganten as she was no longer a commoner. The difference between nobility and the lower class people in Java appears in the use of names and nobility titles. Kartodirdjo (1993, p. 48-51) said that priyayi, either man or woman, is called bendoro. This title is used in all priyayi characters in the novel such as Bendoro, Bendoro Betawi, Bendoro Guru, Bendoro Putri Demak. Priyayi, in Javanese kingship, is based on two categories, namely, heredity factor such as Bendoro, Bendoro Betawi, Bendoro Putri Demak and profession factor such as Bendoro Guru. Priyayi, which is based on profession, may be from heredity line of priyayi as well since in the early 20 th century, education was still limited to the priyayi society. In line with this, Bendoro's children are called agus that means a boy and rara, which connotes a girl. After being grown up and getting married, people call them as agus and Raden Nganten.

The hierarchy system does not recognize equality and fratemity, even between brother and sister. Therefore, after being a part of the aristocracy, there was a gap between the Girl and her parents.

"Did I hear you right?" he repeated, in a harsher, more threatening voice.

"No one dares to speak to the first lady like that," the servant reminded him.

The father sank defeated into a chair. He.could face storms and hurricanes, but his strength lay shattered in this bridal room. ........

"If the first lady wanted," the servant continued, "she could have you driven from this room." (Toer, 1991, p. 25)

The very hierarchy was obvious in the relationship of the characters in Bendoro's mansion. Bendoro has the highest position in his mansion followed by the Girl and his servants. His position was unalterable except by God in which everyone in the manor must devote to him. The servants called themselves sahaya (servant or slave), which also happened to the Girl, even though she was the Bendoro's wife. In -front of Bendoro, she was still a 
commoner who must comply with him. These people performed the custom showing subordination such as squatting down when they are walking towards the Bendoro and bowing when they come to him. Besides, the Girl is not allowed to have guest. In addition, the marriage between the noble and commoner is not legal so that the priyayi is still considered as a bachelor. The marriages done before Bendoro got married with the person with the same social standing were considered only practice marriages. The following is the conversation of Mbok with herself:

.......... Long experience had taught me about the differences between commoners and the nobility in this part of the country. A Bendoro who had married a commoner was not considered married at all, even if they had a dozen children. Such a marriage was only preparation for the noble's proper marriage to a woman of his same social standing. (Toer, 1991, p. 50)

Another indication of feudalism existence in the novel is using a dagger as a tool to represent a noble who wants to marry the Girl from the coast. It is believed that a Javanese man will only become a perfect man when he has obtained five symbolic substances, namely, curiga (dagger), turangga (horse/vehicle), wisma (house), wanita (woman, particularly wife), kukila (bird). Curiga, the dagger, symbolically means maturity, bravery, and masculinity. The dagger in Javanese tradition is a weapon and equipment in Javanese spiritual culture. A traditional Javanese man must be tough and be able to protect himself, his family, and his country in which this ability is symbolized with the dagger. (http://asidharta.blogspot.com/2007/07/kerisapakah-itu.html).

\section{d. Keris (dagger)}

Related to the function of dagger, in a Javanese process of marriage, if a groom cannot attend the marriage as he has something to do in a different place; he can be represented symbolically with his dagger. In the ceremony, the

- dagger is treated like the groom himself and placed side by side with the bride. The traditional Javanese people consider this sort of marriage legitimate even though the groom does not physically attend the process (http://asidharta.blogspot.com/2007/07/keris-apakah-itu.html). Pramoedya took this belief in the novel when Bendoro represented himself with his dagger 
to marry the Girl. In the marriage, Bendoro intentionally represented himself with the dagger-not because of his inability o attend but because of his status which is much higher than the Girl's status is in which the upper class people believed that marrying a common folk was not considered to be a real marriage. In other word, it is not respectable for the noble to marry a member of the lower class people. Afterwards, when the entourage of the Girl's family came in the Bendoro's mansion, they did not have a warm welcome by the Bendoro. The situation seemed usual as if there was no marriage at all. Moreover, a servant in Bendoro's house said that Bendoro was still sleeping, and nobody dared to disturb his sleeping (p. 17-18). To make the matter worse, another servant said that only a commoner who married with a dagger (p. 56).

- "Last night she had been married. Married to a dagger. ....... She was married to a keris, the symbol of a man she had never seen before in her life."(Toer, 1991, p. 1)

Bendoro used the dagger, a symbol that legitimates his domination in his relation to the woman and that represents manliness and courage of the man. By sending the dagger, the man does not have to attend the marriage ceremony. On the contrary, in Javanese culture, if a woman cannot attend a wedding ceremony, she is not allowed to represent herself with a dagger or anything else that symbolizes femininity. Consequently, the fact shows inequality between sexes.

- Being born as a commoner makes the Girl cannot wish for having such a ustial marriage procession though her husband is from a high social standing. She has to accept that she is married to a keris as the representative of the Bendoro. As a common folk, the Girl has to believe it as something destined by nature and sanctified by tradition. It might be understood that in the eyes of tradition, it is not proper for a noble to marry a commoner. Therefore, the keris represents him. The following quotation shows Pramoedya's criticism through the voice of mBok, the servant, toward the custom, which position the common woman in the same place as a material good. The author masterfully shows his criticizing attitude by stating that $\mathrm{mBok}$ at first did not realize she was saying about the concept practiced in the noble world that she finally continued to explain why the custom happened in which it was her effort to disguise such particular custom voiced by the writer. 
" "The keris is only for marrying a common folk," the servant said, before she realized what she was saying. "I meant that if the man can't be there for some reason, then he sends his keris in his place."(Toer, 1991, p. 33)

Although the marriage was only represented by a dagger, the Girls' parents have been pleasant as it was graceful to have a daughter married by a noble. It was very different from the Girl who was morose when she has to leave her home village and her beloved family and friends and kept asking why she could not stay in her world. During the trip to the Bendoro's mansion, her parents kept on persuading The Girl about the honor and wealth that she would get if she became the wife of a noble. The Girl did not respond because for her, the real happiness is in her village. She had never felt any shortage even though she lives in poverty in the village.

A rigid limitation of social-mobility is a characteristic of feudalism. It appears in the form of Javanese marriage that is based on the principle of bibit, bobot, and bebet, which are defined as the origin of the family, wealthy, and priyayi's personality. The nobles, realizing their status, will maintain and raise the position by marrying women whose status is the same as their status. In the novel, to carry out this principle, Bendoro Putri Demak asks Bendoro to get marry with a woman from the same social status, thus, she sends Mardinah, a servant, to force out the Girl from the Bendoro's house. " ... someone of higher status sent me here. It is time the Bendoro was properly married to a real noble." (Toer, 1991, p. 86). Therefore, the Girl's marriage was considered as a practice marriage before the noble had the proper marriage with the same social class.

\section{Closing Remarks}

Pramoedyas' grandmother is the prototype of the Girl from the coast physically and physiologically. Nonetheless, the Girl is still different from his grandmother since Pramoedya obviously inserts his ideas materialized in some characters. These characters evidently become the writer's vehicle to criticize his contradictive stance with the worldviews practiced by the Javanese people in the earlier time. The Girl transformed herself from a plain girl from a fishing village into a matured woman who realized with social condition surround her. Her consciousness brings her to oppose the concepts spread and-materialized by the 
aristocrats even though it is not ended with the victory or successful conclusion for the main character. In fact, the ending of the plot did happen to-Pramoedya's grandmother in the reality.

- Pramoedya attempts to show his viewpoint in the society through the dialogues and the attitudes of the characters in the novel, particularly the commoners. Even though the ending is not contended, the author explicitly launches his satire and criticism through the conversation of among the characters and the inequity performed by the Javanese nobility in the novel. These disapprovals consist of the concept behind wayang, the disparity relationship "between the spouses, the hierarchy between the noble and the commoner, and the use of dagger in the marriage process. Pramoedya ended his plot by illustrating the Girl's refusal to go back to her fishing village. Without looking back again, she focuses her sight in front. In other word, she does not want to go back to her past and decides to find a new life in a different place as a free woman.

Pramoedya deeply understands that authors have great role in creating good sense in society through their works. Therefore, he often reflects the struggle for raising human dignity in his compositions including The Girl from the Coast. In summary, this novel is a work, which loads aesthetic quality as it contains the writer's effort to negotiate his ideas as the form of his consciousness to construct good sense in the society.

\section{Bibliography}

Encyclopedia Britannica. (15 ed.). (1993). (Vol. V, p. 199). Chicago.

Fauzie, I. A. (2003). Fiksi dan Sejarah dalam Karya Pram dalam Esei-esei Bentang 2003. In B. Redona et al (Ed.). Jakarta: Kompas.

Geertz, C. Trans. Abangan, Santri, Priyayi dalam Masyarakat Jawa. Jakarta: Pustaka Jaya. 1981

- Herujiyanto, A. (2007). Pedagogical and Biographical Aspects in.Gabriel Garcia Marquez's one Hundred Years of Solitude. Journal Phenomena Vol. 11 No. 1.

Kartodirdjo, S., et al. (1993). Perkembangan Peradaban Priyayi. Yogyakarta: Gadjah Mada University Press.

Kuntowijoyo. (2006). Raja, Priyayi, dan Kauula. Surakarta: Ombak. 
Magnis, S. (2005). Dalam Bayang-bayang Lenin: Enam Pemikir Marxisme dan Lenin sampai Tan.Malaka ( $2^{\text {od }}$ ed.). Jakarta: Gramedia Pustaka Utama.

Manuaba, P.I.B. (2003). Novel-novel.Pramoedya Ananta Toer: Refleksi Pendegradasian dan Interpretasi Makna Perjuangan Martabat Manusia. Journal Humaniora Volume XV No.3.

Moedjanto, G. (2001). Preface. In H. Antlov and S. Coderreth (Ed.), Kepemimpinan Jawa, Perintah Halus, Pemerintahan Otoriter. Jakarta: Yayasan obor Indonesia.

Puspita, I. (2009). Proceedings from the $2^{\text {nd }}$ RAFIL 2009: Naturalism vs. Modernism in (Eastern Values vs. Western Values) in Pramoedya Ananta Toer's The Girl from the Coast. Yogyakarta: Sanata Dharma University.

Toer, K. S. (2006). Pramoedya Ananta Toer dari Dekat Sekali.: Catatan Pribadi Koesalah Soebagyo Toer. Jakarta: Kepustakaan Populer Gramedia.

Toer, P. A. (1997). Nyanyi Sunyi Seorang Bisu II: Catatan-catatan dari Pulau Buru. Jakarta: Lentera.

Toer, P. A. (1995). Nyanyi Sunyi Seorang Bisu: Catatan-catatan dari Pulau Buru. Jakarta: Lentera.

Toer, P A. (1991). The Girl from the Coost. (H. Aveling. Trans.). Singapore: Select Book. (Original work published 1987)

\section{Electronic Sources:}

Bloomstran, S. (2002, August 11). The Girl from the Coast. [Review of the book The Girl from the Coast]. Retrieved in http://mostlyfiction,com/excerpts/girlfromcoast.htm

Sidharta. A. Keris, Apakah Itu? Retrieved July 242007 in http://asidharta.blogspot.com/2007/07/keris-apakah-itu.html

Kempf, A. (2002). The Girl from the Coast by Pramoedya Ananta Tour. [Review of the book The Girl from the Coast]. Retrieved in http://www.persimmonmag.com/winter2003/bookreview3.html

Press, J. (2002, August 19). Bound to Java's Huts [Review of the book The Girl from the Coast]. Retrieved from http://www.villagevoice.com/books/0234,press,37590,10.html 